\title{
Creative Thinking and Innovative Teaching of Higher Secondary School Teachers in English bazar and Kaliachak Block of Malda, WB
}

\author{
Dr. Suman Panigrahi
}

\begin{abstract}
The major purpose of the present study was to explore the creative thinking and innovative teaching of higher secondary school teacher in Malda district (Englishbazar and Kaliachak Block). Creativity and innovation in particular have played an important role in education policy. Although good teachers recognize the importance of innovativeness, creative teachers see the development of creativity and originality as the distinguishing mark of their teaching. creative teaching and innovative thinking are an art. In Malda district the Higher Secondary teachers are well settled. Most of the teachers are not having major problems of think creatively or innovate in new idea their teaching. The findings indicate that the majority of the teachers are having some capability of innovative teaching and creative thinking.
\end{abstract}

Keywords: Creative thinking, innovative teaching, Higher Secondary School Teachers, Malda district

\section{Introduction}

Education is a light that shows the mankind the right direction to surge. The purpose of education is not just making a student literate but adds rationale thinking, knowledgebility and self sufficiency. When there is a willingness to change, there is hope for progress in any field. Creativity can be developed and innovation benefits both students and teachers. Education is a light that shows the mankind the right direction to surge. If education fails to inculcate self-discipline and commitment to achieve in the minds of student, it is not their fault. We have to convert education into a sport and learning process has to generate interest in the students and motivate them to stay back in the institution than to run away from it. Teaching for creativity by contrast is seen to involve teachers in identifying children's creative strengths and fostering their creativity according to Harris (1998); creativeity is the skill to design or produce something nobel. Creative thinking involves creating something new or original. It involves the skills of the flexibility, originality, fluency, imagery, associative thinking, attribute listing, metaphorical thinking and forced relationships. The use of innovative methods in educational institutions has the potential not only to improve education, but also to empower people, strengthen govermance and galvanize the effort to achieve the human development goal for the country.

\section{Objectives of the Study}

1) To study the creative thinking and innovative teaching of HS teachers.

2) To study the creative and innovative thinking of H.S. School teachers basing on their gender, locality and medium of instruction.

3) Knowing the level of multimedia learning and ICT awareness among the H.S. teachers.

\section{Study Area}

Malda district lies $347 \mathrm{Km}$ North of Kolkata, the State capital of West Bengal (India). The district of Malda in West Bengal has long and rich historical traditions. Total 15 blocks are in Malda district and between them kaliachak (I + II + III) and Englishbazar blocks are our study area.

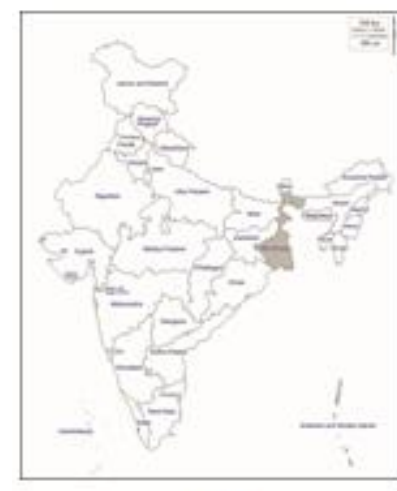

India

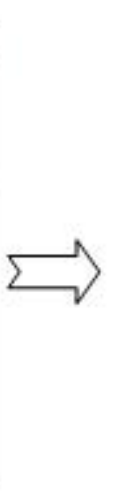

Figure 1: Study Area Location Map

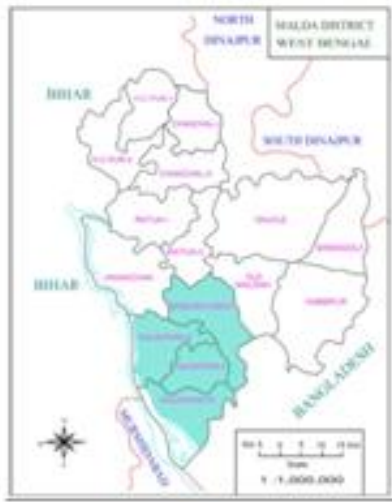

Study area 


\section{International Journal of Science and Research (IJSR) \\ ISSN (Online): 2319-7064}

Index Copernicus Value (2015): 78.96 | Impact Factor (2015): 6.391

\section{Methodology}

After preparing the questionnaire form, the author (also a HS teacher in the study area) visited twenty five (25) different H.S. Schools, ten (10) from Urban and fifteen (15) from rural areas of Kaliachak and Englishbazar block of Malda district. And minimum five and maximum ten trained teachers were interviewed personally from each school for the study of creative and innovative thinking of the H.S. teachers in the study area. The collected data were analized through application of required statistical techniques. And total no. of respondents were 135 .

\section{Result and Discussion}

Nowadays teaching is becoming one of the most challenging professions in India where knowledge is expanding rapidly and much of it is available to students as well teachers at any time and anywhere. As teacher education is primarily directed towards preparing teachers, the quality of teacher education depends on the teacher trainee's abilities, creative and innovative thinking and skills. The National advisory Committee on creative and cultural education suggests that the first task in teaching for creativity is "To encourage young people to believe in their creative potential, to engage their sense of possibility and to give them confidence to try" (NACCCE, 1999, P -90). And according to Ann Coughlan (2007-08) the creative or innovative thinking strategies are Combine some of the features of two different objects or ideas to see if you can create several more Change your routine, do things a different-way, walk a different route to college Be open up ideas when they are still new; look for ways of making things work and pushing the idea to its limits.

\section{Analysis}

Table 1: Showing the male female creative / innovative thinking of H.S. School teachers in the study area. $\mathrm{n}=135$

\begin{tabular}{|l|c|c|c|}
\hline \multicolumn{1}{|c|}{ Subject } & Gender & Total No. & Mean \\
\hline \multirow{2}{*}{$\begin{array}{l}\text { Creative and innovative } \\
\text { thinking }\end{array}$} & Male & 70 & 42.54 \\
\cline { 2 - 4 } & Female & 65 & 44.73 \\
\hline
\end{tabular}

Source: Field Survey

Table 2: Showing the locality and creative / innovative thinking of H.S. School teachers in the study area. $\mathrm{n}=135$

\begin{tabular}{|c|c|c|c|}
\hline Subject & Locality & Total No. & Mean \\
\hline $\begin{array}{c}\text { Creative and innovative } \\
\text { thinking }\end{array}$ & Urban & 46 & 45.50 \\
\cline { 2 - 4 } & Rural & 89 & 46.12 \\
\hline
\end{tabular}
Source : Field Survey

Table 3: Showing the language (medium) and difference in thinking of H.S. School teachers in the study area.

\begin{tabular}{|l|c|c|c|}
\multicolumn{4}{|c}{$\mathrm{n}=135$} \\
\hline \multicolumn{1}{|c|}{ Subject } & Medium & Total No. & Mean \\
\hline $\begin{array}{l}\text { Creative and innovative } \\
\text { thinking }\end{array}$ & Bengali & 118 & 48.17 \\
\cline { 2 - 4 } & English & 17 & 48.01 \\
\hline
\end{tabular}

From above three table it is clear that Source : Field Survey

1) Creative / Innovative thinking of H.S. School teacher changes due to their gender.
2) Creative / Innovative thinking of H.S. School teacher changes due to their locality.

3) Creative / Innovative thinking of H.S. School teracher changes due to their medium of teaching.

\section{Creative / Innovative Thinking and Multimedia Learning in the Study Area}

Multimedia is the combination of various digital media types such as text, images, audio and video; into integrated multisensory interactive application or presentation to convey information to an audience. And multimedia technology as an creative / innovative teaching and learning strategy in a problem-based learning environment is most important.

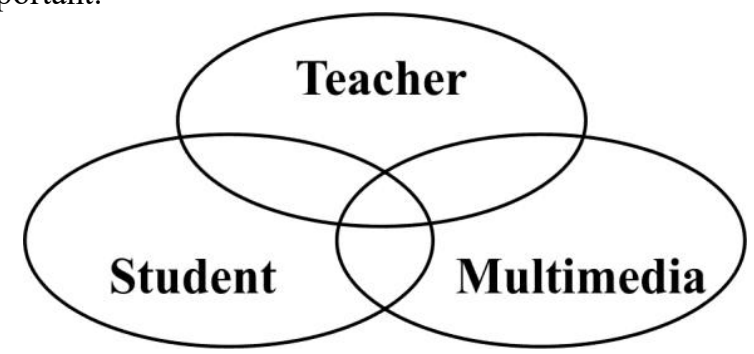

Figure 2: Relation of teacher, student and multimedia

In the study area use of multimedia for teaching is very poor. Few school uses audio but the quality is very low. Some H.S. School teachers uses multimedia for teaching computer (subject) only. Other than they do not use multimedia for their teaching technique as a creative / Innovative thinking.

\section{ICT and Creative / Innovative Thinking of H.S. School Teachers in the Study Area}

Information and communications technology (ICT) in education is the meting out-of information and its communications amenities and features that variously support teaching, learning and a range of activities in education. ICT can and will empower teachers and learners for teaching-learning processes to develop their creativity, innovative problem-solving abilities. Informational reasoning skills communication skill and other higher order thinking skills.

Table 4: Level of ICT awareness and use it as creative / innovative thinking among the H.S. School teacher in the study area.

\begin{tabular}{|c|l|c|c|}
\hline Sl. No. & $\begin{array}{c}\text { ICT and creative / } \\
\text { innovative teaching }\end{array}$ & Frequency & Percentage \\
\hline 1 & Very poor & 7 & 5.18 \\
\hline 2 & Poor & 73 & 54.07 \\
\hline 3 & Average & 42 & 31.11 \\
\hline 4 & Good & 4 & 2.96 \\
\hline 5 & Very Good & 9 & 6.66 \\
\hline & Total & $\mathbf{1 3 5}$ & $\mathbf{1 0 0 . 0 0}$ \\
\hline
\end{tabular}

Source: Field survey

\section{Findings}

There is no significant difference between creative / innovative thinking of male and female; rural and urban; 


\section{International Journal of Science and Research (IJSR) \\ ISSN (Online): 2319-7064 \\ Index Copernicus Value (2015): 78.96 | Impact Factor (2015): 6.391}

Bengali and English medium teachers in two study block in Malda district

Creative / Innovative teaching with multimedia learning is poor in the study area.

$\%$ of ICT and creative / innovative teaching is $54.07 \%$, poor; and $31.11 \%$ is average.

\section{Suggestion}

1) Special creative / innovative development classes are compulsory for newly appointed teachers and less experience teachers.

2) Majority of the teachers are not used creative / innovative thinking in their teaching because of work burden and course completion strategies.

3) Multimedia learning should improved for creative / innovative teaching.

4) If all the teacher have at least one maximum five period in a week for creative / innovative teaching period in their routine / time table it will be change the thinking processes.

5) Use of ICT should be improved; very small percentage of schools achieved this in the study area.

\section{Conclusion}

Without creative / innovative thinking of teacher, methods of teaching could never develop plan effective foundation for critical thinking and understanding for the students. They could learn more when learning became personal and it is only possible by using teacher's creativity and innovative ideas with multimedia and ICT. Through it the learners would be able to construct their own concept and find their own solutions to their problems. The teachers should be given appropriate training for inculcating skills associated to creativity and innovative thinking.

\section{References}

[1] K. Saty. Vani, 2016, "A Study of creative thinking of secondary schools teachers in West Godawari District", IJIR, Vol-2, Issue-8, PP-827-830.

[2] Nabin, Thakur, 2014, “A. Study on Awareness of Trained Teachers in relation to Information and communication Technology", IOSR - JRME, Vol-4, Issue-I, PP- 6-10.

[3] Md. N. Anwar, Md. Aness, Asma Khizar, Md. Naseer and Gulam Md., 2012, IIJE, Vol-I, Issue-3, PP-44-46.

[4] Ozkal, Nese, 2014, "Relationships between teachers' creativity fostering behaviours and their self-efficacy beliefs", Academic Journals, Vol-9, Pp-724-733.

[5] "Creativity and Innovation in the class room", University of Wisconsin — Green Bay, LLC, PP-1-6 (Internet).

[6] Dr. Damodharan V.S. ACCA, AICWA and Mr. Regarajan. V, AICWA, "Innovative Methods of Teaching" (Internet).

[7] Cremin, T, Burnard, P and Craft, A (2006), "Pedagogies of Possibility thinking", International Journal of Thinking Skills and Creativity, $1: 2,108-19$.
[8] Lindstrom, R. (1994), "The Business Week Guide to Multimedia Presentations : Create Dynamik Presentations that Inspire", New York : MC Graw-Hill.

[9] Yenilmez K, Yolcu, B (2007). "Contributions of teachers' behaviour on creative thinking abilities", Social Sci, J. $18: 95-105$.

[10] Yamamoto, K (1964) "A further analysis of the role of creative thinking in high school achievement", Journal of Psychology, 58, 277-283.

[11] A Sha, C. B. (1980), "Creativity and Academic Achievement among Secondary School Children", Asian Journal of Psychology and Education, 6 - 14.

[12] Beena, and Mathur, M (2012), “ A Study on the ICT Awareness of M. Ed. Trainees", International Journal of Business Management and Economic Research, 13 (4) 573-578

[13] Jaiswal, D., (2011) "Role of ICT in Teacher Education", Edutract, 10 (11), PP. 9 - 10. 